\title{
The Economic Improvement of Farmers inSeiLiturTasik Village through Independent Mocaf- Flour Production System
}

\author{
Hatta Ridho, Muhammad Arifin Nasution \\ Faculty of Social and Political Science, University of Sumatera Utara \\ Email: ridhohatta71@gmail.com
}

\begin{abstract}
The abundance of harvest does not always bring a good impact for farmers. Many problems of selling price is always an issue from year to year in Indonesia. This situation was also experienced by the farmers in SeiLiturTasik, District SawitSeberang, Langkat. The low cost of production and the low value of cassava selling demandthe farmer creativity to increase the selling value of cassava as well as the ability of farmers in managerial marketing which can provide more value for the cassava farmers as major manufacturers. Mocaf flour is one solution to raise the peasant economy. Apart from the cheap and easily-obtained raw materials, the Farmers also will have the opportunity to create abusinessas well as their main livelihood as farmers. The Community service method is implemented with multiple stages, which are the preparatory stage, the stage of assessment, the alternative planning stage, the action-plan formulation stage, the implementation stage, the evaluation and monitoring stage, and the termination stage. The purpose of this service program is to establish a group of farmers who have the entrepreneurial spirit. The result of this dedication can improve farmer revived interest in SeiLiturTasikin producing cassava plant as a major resource in SeiLiturTasik. Thus, the farmers in SeiLiturTasikwill get more revenue from mocaf-flour selling since the selling price of unprocessed cassavawould get a markdown.
\end{abstract}

Keywords: Farmer, Production, Entrepreneur

\section{PRELIMINARY}

For countries agrarian, agricultural aspect is an important aspect of the social system, economy, culture, and politics of a country. Including Indonesia, which is an agricultural country where the majority of the population living in the agricultural sector. Indonesia is regarded as an agricultural country can not guarantee its people engaged in agriculture aspects systematized not experience problems. Where one of the problems that are often faced by farmers is a difficulty in post-harvest market access and also the ability of creativity in processing yields increase the value of the sale of crops produced by the farmers.

This problem was also found in farming communities in the Lake District of SeiLiturSawitSeberangLangkat. Sei farming communities in the Lake Litur continue to prioritize cassava (manioc) as a major commodity in the farming community. Activities planting cassava run farming community Sei Litur Lake on land that is surrounded by oil palm plantation PTPN II is a unique phenomenon, whereby a phenomenon of the high interest of other farmers in the Regional District of Saiwit Opposite and surrounding areas for planting palm oil and rubber, the farmers in farmer organization called the Indonesian farmers Union (SPI) in Sei Litur Lake retains to pick crops, namely cassava,

With a variety of underlying basis of the farmers still chooses to plant cassava, one of which is the low cost of production, but the post-harvest issues remain the main problems for the farmers, the sale value of cassava which is quite low at the farm level. The low cost of production and the low value of selling cassava at the level of farmers demanding their creativity in increasing the sale value of cassava as well as the ability of farmers in marketing managed that can provide more value for farmers as a major manufacturer which produces the cassava. Demands for increased capacity of farmers is also a form so that an increase in capacity and self-confidence to 3 use power and by transferring power from the environment to clientsí ".

Based on the potential of social resources and the natural resources available in the Lake District of SeiLiturSawitSeberangLangkat very appropriately carried out community service activities, especially for groups of farmers producing cassava flour mocaf. As for the solution and targetoutcome, in this case, is to the economy through increasing farmers' groups through a 
system of independent production mocaf flour. Where economic improvement that is run by using this method is with a community development based on the socio-economic conditions of farmers and with the goal of increasing the peasant economy.

To increase cassava farmer economy SeiLiturTasik by mokaf flour production, then do some activities such as group discussion forums, education, and understanding of organizational management, training mokaf flour manufacture, marketing and education and training. Through this series of activities is expected that the farmers in the village of SeiLitur to improve living conditions and their income to meet their daily needs. Also expected farmers to produce crops while maintaining and cassava, which is a major power and a typical source in SeiLitur Lake.

\section{METHOD OF EXECUTION}

Implementation of community service activities has several stages, including the preparation stage, the stage of assessment, planning an alternative activity, stage of formulation of the action plan, implementation, evaluation, and monitoring, until the last stage is termination. In the execution (implementation) activities of the local partners, namely the FGD, Understanding Education Management, Training Making Flour Mocaf, and Education and Training Marketing, carried out in stages and also have some focus as well as the equipment and supplies required in the implementation.

FGD implementation of this activity focused on brainstorming presented participants and lead to social and economic resource mapping the community group of partners, through the FGD results expected activities could focus on solving the major problems experienced farmers SeiLitur Lake. Based on the results of assessments at the beginning to decide the number of participants and the time of its implementation, FGDs have conducted simultaneously afterward also executed anyway Understanding Educational Organization, held on August 13, 2017, with the main participants, amounting to two people named Saenan and Dedek. Therefor, in the course of training other residents is also allowed to participate.

Based on the results of FGD conducted, it can be concluded that farmers' revenues decreased due to a decrease in the price of cassava that has not been processed, it is then triggered turunna interest of farmers in cassava due to the incompatibility to plant production costs with sales prices obtained by farmers.

Through discussion results obtained, it is concluded that the steps that can be doneare by cassava to be sold at a decent price. Through the discussion and study of the material then decided to conduct a cassava to make flour mokaf.

See the existing problems, the first thing to do is to provide an understanding of organizational management related. By providing an understanding of the organization's management is expected to farmer groups who do it will be able to run the entire process starting from production to marketing with the right corridor.

The next stage is conducted training mocaf flour manufacture. Initial problems experienced by the recognition of farmers who previously had tried to commit mocaf processed flour, but the results have always failed.

Things then do to do counseling related to the processing of cassava into flour mocafcorrect step by step. After melewat extension phase, then the flour-making training activities mocaf farmers do SeiLiturTasik that all activities are guided and monitored regularly.

After counseling, the thing that makes the conclusions drawn farmer groups always fail in business is the production of flour mocaf potato election who have not reached the appropriate age and lack of hygiene in the production process. At this stage, cassava is still about 8-12 months old is harvested. After that harvesting, the Cassava decent selection process (without a black spot) is performed. The quantity of cassava used in the training of about $300 \mathrm{~kg}$.

The next stage in the process of making flour mocaf is stripping and washing. Things become a major concern is hygiene equipment used. The water used for soaking water should be clean and not contaminated at all. For maximum results can be used water continues to flow to bring the whole dirt in cassava.

After cassava cleaned then carried erosion. To get maximum results, the recommended thickness is $1.5 \mathrm{~mm}$. The fermentation process is then performed by inserting cassava into burlap and soaked for 3 days. The process is done next is the salting is done by soaking cassava in water that has dissolved salts. 
To produce the best quality flour mocaf with the cassava which has passed through a series of processes must pressed ntil it runs out of cassava starch. It can be seen through the water carried in the process of pressing when the water is coming out already clear then the meaning of cassava starch has been exhausted. Furthermore, cassava must be dried, in this event, the team takes up to 4 days for only rely on the sun on as the primary source of drying.

After dry, cassava flouring then performed with a machine that has been provided. In practice, cassava which has entered the stage of flouring should be sieved to ensure no parts are still crude shipped to the packaging stage. After obtaining flour with good quality, then the packaging process. The thing to note is packed with attractive packaging, considering that the main focus of product sales are upper middle class.

After mocaf product is successfully created, then do marketing training activities led by HattaRidho S. Sos., MSP. In this case, the education marketing is done by an informal forum format by involving farmers who want to be involved, but it is reserved for those farmers who will focus on managing the business units in cooperative marketing distribution service targeted participants.

Based on the discussions it was agreed thepackagingis done for load mocafmocaf flour as a healthy food. Another point of focus is to try to take advantage of social media as a marketing media product.

\section{RESULTS AND DISCUSSION}

The problems experienced by Farmers SeiLiturTasik before this activity is done crop cassava (cassava) is the major plant species for farmers SeiLitur. Although seriring time there have been several farmers who convert most of their land to plant rubber (Rambong) due to the selling price of cassava at a fairly low level of farmers. However, until now the group of partners in the process of agricultural production continues to prioritize the cassava plant as a major crop due to low production costs are considered. With the condition of low production costs and the selling price is still low at the farm level, we need a form of alternative to increase the sale value of cassava, which is a priority for farmers plant species group partners.
Service activities conducted in DesaTasikLiturSei has a main goal of improving economic returns Farmers up to two million per month. Moreover, this activity is expected by farmers also know the map of natural resources and social resources capable of creating development business units they have.

After a whole series of activities carried out, the farmers look grama eager in making cassava crop production activities. This is the effect of starch processing the result mocaf made by farmers. After doing this farmers Sei Litur Tasik disclose their income increased due to high buyer interest mocaf flour. The production costs for this deficit slowly getting back to normal and make farmers can meet the needs of their daily lives.

Another achievement obtained through these activities is the increasing number of jobs in SeiLitur Lake. The wife of the farmer in the village of Lake SeiLitur now also be able to generate additional revenue to help the processing of flour mocaf, usually the wives of farmers have participated in the process of slicing the cassava will be processed. The addition of other employment opportunities derived from marketing sector which was helped by people who are mostly still young.

Through this activity, the farmers in the village of SeiLitur Lake also maximize cassava as their main production. Farmers are now also able to provide teaching and his fellow counseling related to the manufacture and processing of flour mocaf. It then also lures back the interest of farmers who had switched to the rubber plant to re-grow cassava, which is a major natural resource that can be produced in SeiLitur Lake.

\section{CONCLUSION}

Community service activities in the form of flour production in SeiLiturmocafTasik conducted Institute for Research and Community Service (LPPM extraordinary gain on the SeiLitur farmer groups. It can be seen from the various series of events attended by all members of the group. The results of the process of this devotion have been able to form a working team mocaf flour production. Even in actual production group has made the sale of production to the surrounding community.

Through service activities Economic Improvement Farmers Group SeiLiturTasik through Independent Production Systems Flour 
Mocaf done, farmers feel the benefits are quite large. During this time the farmers still lack understanding, concerning processed agricultural products and mapping of natural resources and social. Farmers also lack understanding related to organizational management and good marketing system. After the service activities by farmers got a new understanding of related business units, marketing and processing agricultural products. Through a new understanding that owned the peasants, they were able to create new job opportunities for the people around them.

\section{BIBLIOGRAPHY}

Chamala, R.S., 1995. Overview of Participative Action Approaches in Australian Land and Water Management. DalamChamala, S. and Keith, K. (eds), 1995.Participative Approaches for Landcare: Perspective, Policies, Program. Brisbane: Australian Academic Press.

Effendi, OnongUchjana 2003. IlmuKomunikasiTeoridanPraktek. Bandung: PT. RemajaRosdakarya.

Hikmat, H., 2004. StrategiPemberdayaanMasyarakat. Humanika. PenerbitHumoniora, Bandung.
Kartasasmita, Ginandjar, 1996. Pembangunan Untuk RakyatMemadukanPertumbuhandanPemerataa $n$. Penerbit PT. Pustaka CIDESINDO, Jakarta.

Khairuddin, 2000. Pembangunan Masyarakat., TinjauanAspek: Sosiologi, EkonomidanPerencanaan. Liberty, Yogyakarta.

Ife, J.W., 1995. Community Development: Creating Community Alternatives-vision, Analysis, and Practice. Melbourne: Longman.

Prijono, O.S. danPranarka, A.M.W., 1996. Pemberdayaan: Konsep, KebijakandanImplementasi. Centre for Strategic and International Studies, Jakarta.

Sumodiningrat,

$\mathrm{G}$.

(1999). PemberdayaanMasyarakatdanJaringPen gamanSosialJakarta: Gramedia.

Syahyuti, 2006. 30 KonsepPentingdalam Pembangunan PedesaandanPertanian. Jakarta : Bina Rena Pariwara. West, Richard\& Lynn H. Turner. 2009. PengantarTeoriKomunikasi: AnalisisdanApilkasi. Jakarta: Salemba 